\title{
Sulfate reduction, acetate turnover and carbon metabolism in sediments of the Ao Nam Bor mangrove, Phuket, Thailand
}

\author{
Erik Kristensen ${ }^{1}$, Gary M. King ${ }^{2}$, Marianne Holmer ${ }^{1}$, Gary T. Banta ${ }^{1}$, \\ Mikael H. Jensen ${ }^{1}$, Kim Hansen ${ }^{1}$, Nipavan Bussarawit ${ }^{3}$ \\ ${ }^{1}$ Institute of Biology, Odense University, DK-5230 Odense M, Denmark \\ ${ }^{2}$ Darling Marine Center, University of Maine, Walpole, Maine 04573, USA \\ ${ }^{3}$ Phuket Marine Biological Center, PO Box 60, Phuket, 83000 Thailand
}

\begin{abstract}
Rates of sediment $\mathrm{O}_{2}$ uptake, $\mathrm{CO}_{2}$ production, sulfate reduction and acetate turnover were examined during January 1992 in the Ao Nam Bor mangrove, Phuket, Thailand. The impact of air exposure on $\mathrm{O}_{2}$ uptake was most pronounced in the intensely bioturbated high-intertidal zone (6.4 times higher than during water cover), and decreased to almost zero in the low-intertidal zone. This indicates a gradual increased area of sediment-air contact zones with tidal elevation due to changes in surface topography. Based on an average water cover for January, the diurnal $\mathrm{O}_{2}$ uptake - and thus total decay of deposited detritus - was 4 to 5 and 8 times faster in the high-intertidal compared to the mid-and low-intertidal zones, respectively. Sulfate reduction rates were generally low. The depthintegrated $(0$ to $30 \mathrm{~cm})$ sulfate reduction was highest in the mid-intertidal zone, and supported $85 \%$ of the estimated daily $\mathrm{CO}_{2}$ release. In the high- and low-intertidal zones, sulfate reduction supported 11 and $92 \%$, respectively, of daily $\mathrm{CO}_{2}$ release. Rates of acetate uptake were also higher in the midthan in the low-intertidal zone (no data from high-intertidal). However, the depth-integrated acetate uptake was consistently about 2.6 times the rates of $\mathrm{CO}_{2}$ release and 5 to 6 times the 0 to $11 \mathrm{~cm}$ integrated sulfate reduction, which suggests that pool sizes of acetate and thus uptake rates may have been overestimated. In conclusion, while benthic respiration in the mid-and low-intertidal zones of the Ao Nam Bor mangrove was dominated by sulfate reduction with acetate as carbon source, 'suboxic' conditions related to bioturbation in the active high-intertidal sediment made respiration by other electron acceptors than $\mathrm{SO}_{4}{ }^{2-}$ more important.
\end{abstract}

KEY WORDS: Mangrove sediment - Thailand - Carbon metabolism - Sulfate reduction - Acetate turnover . Tidal variation

\section{INTRODUCTION}

The most important factors controlling sediment metabolism in tropical mangrove swamps are inundation frequency, and quantity and quality of organic input (e.g. Alongi 1989, Wattayakorn et al. 1990, Kristensen et al. 1992). However, depending on location and season, factors like crab bioturbation, monsoon storms and human deforestation also can affect the structure and activity of the benthic community considerably (Chansang et al. 1982, Hylleberg \& Nateewathana 1984, Robertson \& Daniel 1989).
Based on tidal height and inundation frequency, mangrove forests can be divided into low-, mid- and high-intertidal zones, corresponding roughly to the gradations in the extremes and means of spring and neap tides (Alongi 1989). These zones are characterized by specific tree communities and sediment composition. The low-intertidal zone (mudflats or creek banks) is usually characterized by patchy growth of Avicennia species in sandy and silty sediment. The mid-intertidal zone is dominated by dense growth of Rhizophora species in silty, high-organic sediment with peat-like appearance. In the high-intertidal zone 
various mixtures of tree species are found, in many cases dwarfed due to high salinity, dry sediment and nutrient deficiency (Lugo \& Snedaker 1974).

Organic input to the sediment in the various zones is dominated by litter fall and root growth of the tree species present (e.g. Flores-Verdugo et al. 1987, Komiyama et al. 1987). While the ultimate deposition sites of litter are controlled by tidally dominated horizontal transport (e.g. Lugo \& Snedaker 1974, Wattayakorn et al. 1990), root materials will be decomposed within the sediment where they are produced. Sediment detritus in mangroves is usually nitrogen-poor (high $\mathrm{C}: \mathrm{N}$ ratio) with high contents of cellulose and lignin (Benner \& Hodson 1985, Kristensen 1990). These materials decompose slowly - especially under anaerobic conditions - due to their aromatic nature, and due to a general nutrient limitation of microbial decomposers (e.g. Gonzalez-Farias \& Mee 1988, Alongi 1989, Enriquez et al. 1993). Since oxygen is depleted below a few $\mathrm{mm}$ depth in mangrove sediments, even when the surface is exposed to air, anaerobic metabolism predominates with decomposition mediated primarily by fermentation and sulfate reduction (Kristensen et al. 1992). The quantitative role of sulfate reduction may, however, vary depending on tidal elevation and thus the general oxidation state of the sediment (e.g. Nedwell \& Abram 1978, King 1988, Kristensen et al. 1991).

The low molecular fraction of dissolved organic carbon (DOC) (e.g. acetate and other short-chain fatty acids) is usually considered the most important substrate for sulfate-reducing bacteria in marine sediments (Ansbæk \& Blackburn 1980, Balba \& Nedwell 1982, Parkes et al. 1984, Shaw et al. 1984). Although the labile fraction of leachable organics from mangrove leaves is mineralized rapidly after incorporation in sediment, a large fraction of the DOC pool is composed of tannins and phenolics which may hamper or even inhibit - microbial activity (Benner \& Hodson 1985, Gonzales-Farias \& Mee 1988).

The purpose of this work was to determine the role of acetate uptake and sulfate reduction for benthic metabolism and organic matter decay at 3 tidal elevations in a southeast Asian mangrove swamp (Ao Nam Bor). The impact of air exposure on benthic fluxes of $\mathrm{O}_{2}$ and $\mathrm{CO}_{2}$ was evaluated and related to crab bioturbation and sources of organic input in the sediment. This work is a continuation and comprehensive extension of a previous study on benthic metabolism at the same location (Kristensen et al. 1991).

\section{MATERIALS AND METHODS}

Site description. Samples were collected during January 1992 in a 300 m wide mangrove forest, Ao Nam
Bor, in Makham Bay, ca $4 \mathrm{~km}$ south of Phuket Town on the east coast of Phuket Island, Thailand. A detailed description of the study site is given by Frith et al. (1976). The 3 stations described by Kristensen et al. (1991) were also chosen for this study. Stn 1 was situated close to the landward fringe on a nonvegetated bank adjacent to a small (ca $1 \mathrm{~m}$ wide) creek. This high-intertidal station was heavily bioturbated by ocypodid and grapsid crabs (1046 \pm 508 burrow openings $\mathrm{m}^{-2}$; G. T. Banta unpubl.). Stn 2 was located within the mangrove forest between 'prop' roots of Rhizophora apiculata ca $50 \mathrm{~m}$ from the seaward fringe. This mid-intertidal station was moderately affected by burrowing fauna $(41 \pm 6$ crab burrows and $500 \pm 62$ sipunculid worms $\mathrm{m}^{-2}$ ). The low-intertidal Stn 3 was located on the tidal flat ca $100 \mathrm{~m}$ outside the forest. The dominating burrowing animals were ocypodid crabs $\left(8 \pm 1 \mathrm{~m}^{-2}\right)$, mudskippers (Gobioidae) (about $5 \mathrm{~m}^{-2}$ ) and small (1 to $3 \mathrm{~cm}$ long) polychaete worms of unknown species $\left(1400 \pm 600 \mathrm{~m}^{-2}\right)$. Salinity and water temperature at all 3 stations were 33 to $35 \%$ and 28 to $33^{\circ} \mathrm{C}$.

$\mathrm{O}_{2}$ and $\mathrm{CO}_{2}$ flux. Rates of benthic metabolism were estimated from $\mathrm{O}_{2}$ uptake and $\mathrm{CO}_{2}$ production of water-covered (+W-core) sediment and $\mathrm{O}_{2}$ uptake of air-exposed $(-\mathrm{w}$-core) sediment. Sediment cores were taken by hand at low tide during day using $8 \mathrm{~cm}$ i.d. and $25 \mathrm{~cm}$ long (+w-core) or $15 \mathrm{~cm}$ long (-w-core) acrylic core tubes. Diffusive $\mathrm{O}_{2}$ flux in both light and darkness ( + w- and -w-profile) was estimated from $\mathrm{O}_{2}$ microprofiles measured on cores used for flux incubations. Cores were usually processed in the laboratory within $2 \mathrm{~h}$ after sampling.

For $+w$-core flux incubations, 4 cores $(13 \mathrm{~cm}$ sediment and $9 \mathrm{~cm}$ headspace) were sampled per station. In the laboratory, the still air-exposed cores were preincubated in the dark in a water bath at $29^{\circ} \mathrm{C}$. After 1 to $4 \mathrm{~h}$, seawater was carefully added and cores were submerged. Flux rates of $\mathrm{O}_{2}$ and $\mathrm{CO}_{2}$ were obtained by standard closed-core incubations according to Kristensen et al. (1991). Flux rates were determined during incubation periods of 2 to $7 \mathrm{~h}$. Oxygen was measured by a mini Clark-type $\mathrm{O}_{2}$ electrode (Microelectrodes, Inc.) inserted into the gently stirred water column. At least 4 measurements were made at regular intervals during the incubation period. Care was taken not to let the $\mathrm{O}_{2}$ concentration in the overlying water drop lower than $60 \%$ of air saturation. The $\mathrm{O}_{2}$ results presented from Stn 2 are based on Winkler data due to electrode malfunction. Total carbon dioxide $\left(\mathrm{TCO}_{2}\right)$ was quantified at the start and end by potentiometric Gran titration (Talling 1973). Flux measurements for $+w$-cores were made on 2 consecutive days. Cores were drained and held in the seawater tank with air-exposed sediment for 6 to $12 \mathrm{~h}$ between incubations to simulate low tide. As the 2 measurements for the 2 days generally 
agreed within $10 \%$ the results are presented as the average.

Oxygen uptake by the sediment at low tide $(-\mathrm{w}$-core) was estimated from the $\mathrm{O}_{2}$ decrease in the headspace of sealed, air-exposed cores (Kristensen et al. 1992). Four cores ( $11 \mathrm{~cm}$ sediment and $3 \mathrm{~cm}$ headspace) were incubated in darkness at each station. After a 1 to $2 \mathrm{~h}$ acclimation period in the laboratory at $29^{\circ} \mathrm{C}$, a rubber stopper, with a Clark-type $\mathrm{O}_{2}$ electrode (Radiometer, Denmark) inserted through a hole in the center, was fitted to the core liner allowing about $2 \mathrm{~cm}$ air space above the sediment. After 10 to $15 \mathrm{~h}$ the final electrode reading was noted. Subsequently, the $\mathrm{O}_{2}$ electrode was calibrated to air saturation (equivalent to the start concentration). Oxygen uptake was calculated using the concentration change and air volume trapped below the rubber stopper.

Depth penetration of $\mathrm{O}_{2}$ into the sediment was measured by a polarographic needle $\mathrm{O}_{2}$ electrode (Diamond Electro-Tech, Inc.) with a platinum tip diameter of 35 to $40 \mu \mathrm{m}$, providing a spatial resolution of less than $0.2 \mathrm{~mm}$ (Helder \& Bakker 1985). The electrode was mounted on a micromanipulator and connected to a picoammeter. Light (intensity: 1000 to $1500 \mu \mathrm{E}$ $\mathrm{m}^{-2} \mathrm{~s}^{-1}$ ) and dark $\mathrm{O}_{2}$ profiles from the 3 stations were obtained under in situ conditions. Profiles were measured in steps of $0.2 \mathrm{~mm}$ on $8 \mathrm{~cm}$ i.d. cores both with (+w-profile) and without (-w-profile, only in darkness) overlying water. Stirring rate in the water-covered cores was maintained at $10 \mathrm{rpm}$ (water velocity at the site of measurement: 1 to $3 \mathrm{~cm} \mathrm{~s}^{-1}$ ). The diffusive flux of $\mathrm{O}_{2}$ out of and into the sediment was estimated from the steepest gradient below the sediment-water interface by the 1-dimensional version of Fick's first law of diffusion (Berner 1980). The apparent diffusion coefficient of $\mathrm{O}_{2}$ at the sediment-water interface was calculated from porosity data and the temperaturecorrected diffusion coefficient of $\mathrm{O}_{2}$ in seawater (Broecker \& Peng 1974, Berner 1980).

Sulfate reduction. Sulfate reduction was measured by the core injection technique of Jorgensen (1978). Three $40 \mathrm{~cm}$ long and $5.2 \mathrm{~cm}$ i.d. cores from each station were subcored using $2.6 \mathrm{~cm}$ i.d. and $16 \mathrm{~cm}$ long core tubes with silicone-filled injection ports. A volume of $2 \mu \mathrm{l}$ carrier-free ${ }^{35} \mathrm{~S}_{-} \mathrm{SO}_{4}{ }^{2-}(70 \mathrm{kBq})$ was injected at $1 \mathrm{~cm}$ intervals and the cores were incubated with dry surfaces in darkness for $12 \mathrm{~h}$. Subsequently, each subcore was sectioned in 1 to $2 \mathrm{~cm}$ segments and fixed in $20 \%$ ZnAc. Samples were stored frozen until distillation by the 1-step procedure of Fossing \& Jørgensen (1989) and radioassayed within 1 to 3 mo.

Acetate uptake. Pore water acetate: Pore water for acetate analysis from Stns 2 and 3 was obtained by 2 methods - centrifugation ( $1500 \mathrm{rpm}, 500 \times \mathrm{g}$ for $7 \mathrm{~min}$ ) and 'sippers'. The in situ 'sipper' technique was chosen to examine possible artifacts resulting from coring and centrifugation (Howes et al. 1985). Sippers were constructed from narrow-bore capillary tubing ( $1 \mathrm{~mm}$ i.d. $x$ $5 \mathrm{~mm}$ o.d.) with pipet tips containing glass wool and sealed with glass beads attached to one end. The pipet tips were notched to about one-half the circumference to form ports for pore water passage. The opposite ends of the tubing were sealed with serum stoppers. Sippers were slowly inserted vertically into the sediment until the sampling ports were at the desired depths $(1,3,5,7$ and $11 \mathrm{~cm})$. After at least $24 \mathrm{~h}$, pore water (1 to $2 \mathrm{ml}$ ) was collected by needle and syringe through the serum stoppers (first 0.5 to $1.0 \mathrm{ml}$ discarded). Samples were retained in syringes at ambient temperature for no more than $1 \mathrm{~h}$ before being frozen in vials until analysis. Due to the sand content of Stn 3, pore water was obtained readily from all depths. The silty sediment at Stn 2 prohibited sample collection from all except the 1 and $5 \mathrm{~cm}$ depths.

The enzyme-based HPLC technique of King (1991) was used to assay acetate. The samples were incubated with acetyl CoA synthase for $1 \mathrm{~h}$ at $30^{\circ} \mathrm{C}$ and enzyme activity was terminated by boiling for $5 \mathrm{~min}$. AMP produced by the reaction of pore water acetate with added ATP and acetyl CoA synthase was analyzed by HPLC within $4 \mathrm{~d}$. In the interim, samples were stored frozen.

${ }^{3} \mathrm{H}$-acetate turnover: Sediment samples were obtained from $9 \mathrm{~cm}$ i.d. core tubes by slowly inserting cut-off $5 \mathrm{~cm}^{3}$ syringes horizontally into ports arrayed vertically $(1,3,5,7$ and $11 \mathrm{~cm}$ depth). After obtaining 3 to $5 \mathrm{~cm}^{3}$ of sediment, the syringes were sealed with butyl septa, injected with $10 \mu$ l of a ${ }^{3} \mathrm{H}$-acetate solution (ca $3.7 \mathrm{kBq}$ ) and incubated for 5, 15, 30 and $60 \mathrm{~min}$ at $29^{\circ} \mathrm{C}$. Incubations were terminated by extruding subcores into vials containing $0.5 \mathrm{M} \mathrm{NaOH}$. Time zero controls were prepared by extruding subcores into base immediately after injection.

Rate constants of acetate uptake were determined by a modification of the technique described by Sawyer \& King (1993). The sediment-base mixtures were centrifuged and the supernatants dried to remove ${ }^{3} \mathrm{H}_{2} \mathrm{O}$. The residues from drying were neutralized and mixed with a scintillation fluid for radioassay. Rate constants were calculated from a regression analysis of $\ln (D P M$, disintegrations per minute) in the dried pore-water residues as a function of incubation time. Uptake rates were obtained from the product of the rate constants and pore water acetate pool sizes determined as described above.

Molybdate inhibition: Samples of surface sediment were collected by inserting $5 \mathrm{~cm}^{3}$ cut-off syringes vertically into the sediment at Stn 3 and removing the upper $3.5 \mathrm{~cm}$ of the profile. The syringes were sealed with butyl septa and, after 1 to $1.5 \mathrm{~h}, 1$ triplicate set of syringes was injected with $0.5 \mathrm{ml}$ each of $200 \mathrm{mM}$ 
sodium molybdate in artificial seawater. Another triplicate set was incubated as uninhibited controls. The syringes were then incubated for $0,0.5,1.0,1.5$ and $2 \mathrm{~h}$ at $29^{\circ} \mathrm{C}$. At each time point, the syringe contents were transferred into $50 \mathrm{ml}$ centrifuge tubes and centrifuged for 3 to $5 \mathrm{~min}$ at $1500 \mathrm{rpm}(500 \times \mathrm{g})$. One $\mathrm{ml}$ of the supernatant was collected from each sample and frozen prior to acetate analysis as above.

Other sediment parameters. Cores $(5.2 \mathrm{~cm}$ i.d.) for determination of sediment characteristics were sectioned at the same depth intervals as those used for the sulfate reduction assay. Porosity was calculated from wet densities and water loss at $105^{\circ} \mathrm{C}$ for $12 \mathrm{~h}$. Subsamples of the $105^{\circ} \mathrm{C}$ dried sediment were used for Stepwise ThermoGravimetry (STG) to obtain the $R p$ index: (ignition loss from 280 to $520^{\circ} \mathrm{C}$ )/(ignition loss from 130 to $520^{\circ} \mathrm{C}$ ) (Kristensen 1990). Low Rps (around $0.2)$ are typical for materials rich in aliphatic compounds (lipids, carbohydrates), whereas high $R p s$ (>0.5) represent aromatic compounds and materials rich in nitrogen (humates, proteins). Samples of $130^{\circ} \mathrm{C}$ dried sediment were analyzed for particulate organic carbon (POC) and nitrogen (PON) using a Carlo Erba CHNS analyzer. Chlorophyll a from the upper $0.5 \mathrm{~cm}$ sediment was determined spectrophotometrically (Parsons et al. 1984) in 4 replicates per station after extracting the samples in $90 \%$ acetone $\left(1: 6 \mathrm{v} / \mathrm{v}\right.$.) for $24 \mathrm{~h}$ at $5^{\circ} \mathrm{C}$.

\section{RESULTS}

\section{Sediment characteristics}

The sediment at Stn 1 was composed of grey-brown silt $(70 \%$ of particles $<63 \mu \mathrm{m})$ down to ca $20 \mathrm{~cm}$ followed by more sandy texture $(50 \%<63 \mu \mathrm{m})$. Beside a distinct subsurface peak at $2 \mathrm{~cm}$, the organic content showed no significant depth pattern (Fig. 1A, B). Activities of crabs oxidized the upper 5 to $10 \mathrm{~cm}$, as indicated by a light brown color. The underlying reduced sediment was never black and sulfidic. At Stn 2, the sediment was composed of grey-brown silt $190 \%$ of particles $<63 \mu \mathrm{m})$ in the examined depth interval. Organic content was high, about 2 to 3 and 2 to 6 times higher than at Stns 1 and 3, respectively (Fig. 1A, B). Only the upper 4 to $5 \mathrm{~cm}$ was devoid of roots (silt zone); below was a deep root zone with peat-like appearance, which was evident as a $40 \%$ increase in organic content. Visual inspection showed that the proportion of dead roots increased rapidly with depth below $15 \mathrm{~cm}$ in the root zone. The silt zone was never black and sulfidic, whereas scattered spots were apparent around dead roots in the root zone. The sediment at Stn 3 appeared more sandy in the upper centimetres than at the other 2 stations ( $40 \%$ of particles $<63 \mu \mathrm{m}$ ).

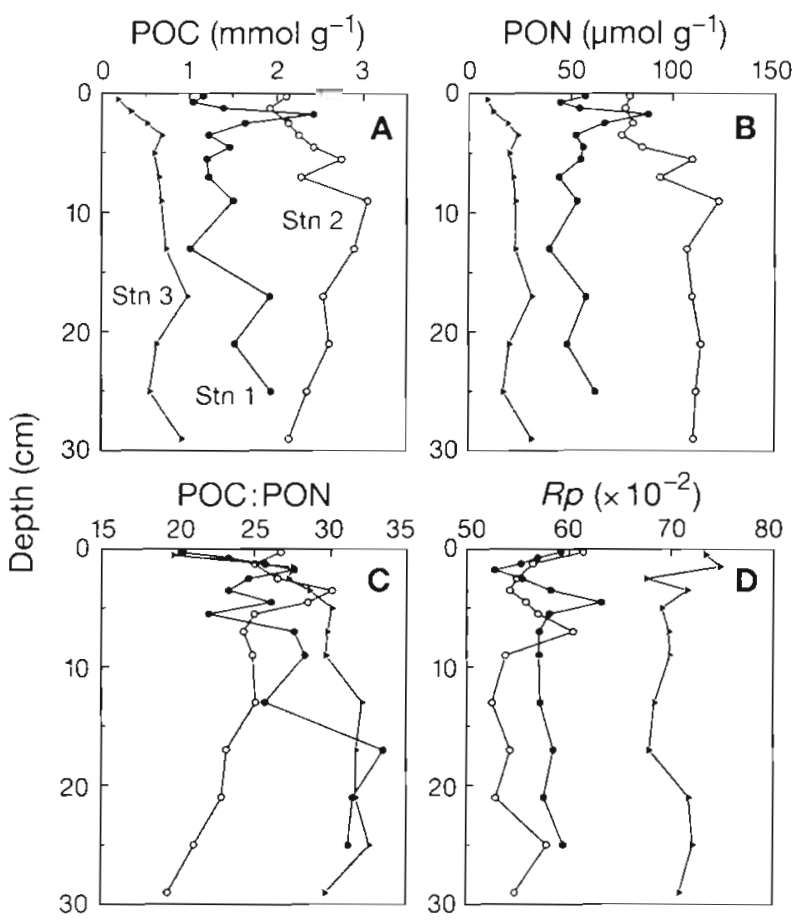

Fig. 1. Vertical profiles of (A) particulate organic carbon (POC), (B) particulate organic nitrogen (PON), (C) POC:PON ratio, and (D) $R p$ index at the 3 stations. Values are mean of 4 determinations. SE of mean for all 3 parameters was less than $20 \%$

The sediment below was homogeneous and consisted of silty, nonsulfidic sand $(70 \%$ of particles $<63 \mu \mathrm{m})$ down to $\mathrm{ca} 30 \mathrm{~cm}$ depth followed by a zone of coarse coral sand. The organic content more than doubled from the surface to $3 \mathrm{~cm}$ depth, and remained constant deeper down. Coral sand below $30 \mathrm{~cm}$ was evident as high concentrations of carbonates, 0.5 to $2 \mathrm{mmol} \mathrm{C} \mathrm{g}^{-1}$ dry wt.

At Stns 1 and 3, the molar C:N ratio of the sediment organic matter increased from 20 to 27 with depth in the upper $2 \mathrm{~cm}$ (Fig. 1C). Further down, C:N at these stations reached a constant level around 31 to 33 with generally highest values at $\operatorname{Stn} 3$. At Stn 2, the C:N ratio gradually decreased from 27 close to the surface to 20 at $30 \mathrm{~cm}$ depth, except for a peak around 3 to $4 \mathrm{~cm}$ depth $(C: N=30)$. At all stations the $R p$ index varied irregularly (Fig. 1D) with depth in the upper 5 to $10 \mathrm{~cm}$, and remained constant deeper down. Highest values, indicating a humified organic pool, were observed at Stn $3(R p=0.65$ to 0.75$)$. Stns 1 and 2 covered similar ranges $(R p=0.52$ to 0.63$)$, but with a trend for lowest values at Stn 2 below $3 \mathrm{~cm}$ depth, indicating the presence of carbohydrates, such as cellulose, from roots

The chlorophyll a concentration in the upper $0.5 \mathrm{~cm}$ was highest at Stn $3\left(1.63 \pm 0.26 \mu \mathrm{g} \mathrm{g}^{-1}\right.$ dry wt), almost twice the content at Stns 1 and $2(0.98 \pm 0.12$ and $0.88 \pm 0.30 \mu \mathrm{g} \mathrm{g}^{-1}$ dry wt, respectively). 


\section{$\mathrm{O}_{2}$ and $\mathrm{CO}_{2}$ flux}

The tidal shift between air exposure and water cover resulted in significant ( $t$-test, $\mathrm{p}<0.01$ ) differences in $\mathrm{O}_{2}$ flux at Stns 1 and 2. At the highly bioturbated Stn 1 , measured -w-core $\mathrm{O}_{2}$ uptake was 6.4 times higher than $+w$-core rates (Table 1). The difference was a factor of 1.8 at Stn 2 and 0.98 at Stn 3. Diffusive fluxes of $\mathrm{O}_{2}$ estimated from microprofiles in darkness showed a similar trend, although of lower magnitude (1.6, 1.4 and 1.1 times, respectively; Table 1). Since a film of water was pulled 0.2 to $0.4 \mathrm{~mm}$ above the sediment along with the electrode tip during air exposure, no clear difference in boundary layer thickness was evident between air-exposed and water-covered sediment (Fig. 2). Oxygen penetration into the sediment in darkness was not influenced by the level of water cover, reaching depths of about $1.0,1.4$ and $1.6 \mathrm{~mm}$, respectively (Fig. 2). The diffusive $\mathrm{O}_{2}$ flux (+w- and -w-profile) accounted for 40 to $60 \%$ of the measured $(+w$ - and $-w$-core) flux at all stations, except the $-w$ fluxes at Stn 1 where the profile estimate only accounted for $10 \%$ of the core rate.

The presence of microalgae at the sediment surface was evident from $\mathrm{O}_{2}$ supersaturation in the upper 0.5 to $1.0 \mathrm{~mm}$ of the sediment during light exposure (Fig. 2). Since light intensity and sediment diffusion coefficients $\left(D_{\mathrm{s}}\right)$ were similar at all 3 stations, the degree of supersaturation and upward diffusive flux are indicators of photosynthetic activity. Stn 3 had the most active microflora, producing an $\mathrm{O}_{2}$ saturation at $0.2 \mathrm{~mm}$ depth of $182 \pm 4 \%$. The values for Stns 1 and 2 were $150 \pm 3$ and $119 \pm$ $4 \%$, respectively (Fig. 2). The upward diffusive flux (Table 1) was highly correlated with chlorophyll a content in the upper $0.5 \mathrm{~cm}$ of the sediment $(\mathrm{r}=0.997)$. The high $\mathrm{O}_{2}$ concentrations at the sediment-water interface resulted in 30 to $60 \%$ deeper penetration (Fig. 2) and downward diffusive flux (Table 1) than in darkness.

Measured rates of $\mathrm{CO}_{2}$ release from the sediment were only available during water cover (Table 1). The rates were higher than the measured + w-core $\mathrm{O}_{2}$ uptake, with community respiratory quotients (CRQ) of 1.32, 1.80 and 1.27 for Stns 1, 2 and 3, respectively. By assuming similar CRQ in $+w$ - and $-w$-cores, these values can be used to estimate $\mathrm{CO}_{2}$ release during air exposure (Table 1).

The total diurnal flux of $\mathrm{O}_{2}$ and $\mathrm{CO}_{2}$ at any one station was obtained by integrating $+\mathrm{w}$ - and $-\mathrm{w}$-core rates in pro- portion to the daily duration of water cover and air exposure. The estimates presented in Table 2 are based on the average diurnal water cover for January at the 3 stations $(1.5,7.3$ and $9.6 \mathrm{~h}$ at Stns 1,2 and 3 , respectively). The estimated diurnal rates are 3 to 5 and 8 times higher at Stn 1 than at Stns 2 and 3, respectively.

\section{Sulfate reduction}

Sulfate reduction rates (SRR) at the 3 stations were generally below $100 \mathrm{nmol} \mathrm{cm}^{-3} \mathrm{~d}^{-1}$ (Fig. 3). At Stn 1, the highest rates were found from 4 to $20 \mathrm{~cm}$ and around 25 to $27 \mathrm{~cm}$ depth. SRR in the uppermost $2 \mathrm{~cm}$ and below $28 \mathrm{~cm}$ were low $\left(<10 \mathrm{nmol} \mathrm{cm} \mathrm{cm}^{-3} \mathrm{~d}^{-1}\right)$ at this station. Stn 2 had generally higher rates than Stn 1. The high rates in the upper $15 \mathrm{~cm}$ corresponded to the most active root zone. Below $15 \mathrm{~cm}$, where old and dead roots predominate, SRR dropped sharply. Stn 3 had low rates in the uppermost oxidized $1 \mathrm{~cm}$ followed by higher rates down to 6 to $8 \mathrm{~cm}$ depth. Below $8 \mathrm{~cm}$ rates gradually decreased reaching a very low level $\left(<5 \mathrm{nmol} \mathrm{cm} \mathrm{cm}^{-3} \mathrm{~d}^{-1}\right)$ at $30 \mathrm{~cm}$ depth. No sulfate depletion was evident at any station (M. Holmer, E. Kristensen, G. T. Banta, K. Hansen, M. H. Jensen \& N. Bussarawit unpubl.).

The depth-integrated $(0$ to $30 \mathrm{~cm}$ ) sulfate reduction ( $\sum \mathrm{SRR}$ ) at Stn 2 was about twice the rate at the other 2 stations (Table 3 ). Sulfate reduction in the depth intervals examined could support 11,85 and $92 \%$ of the

Table 1. $\mathrm{O}_{2}$ and $\mathrm{CO}_{2}$ flux at the 3 stations. $\mathrm{O}_{2}$ flux is measured directly in darkness with water cover $(+w$-core) and air-exposed (- $w$-core $) . \mathrm{CO}_{2}$ is measured directly in darkness with water cover ( $+w$-core) and from the obtained community respiratory quotient estimated (est.) during air exposure (-w-core). $\mathrm{O}_{2}$ flux is estimated from microprofiles in light (upwards, 'up'; downwards, 'dn') and darkness (with water cover, ' $+w^{\prime}$; during air exposure, '- $w$ ')

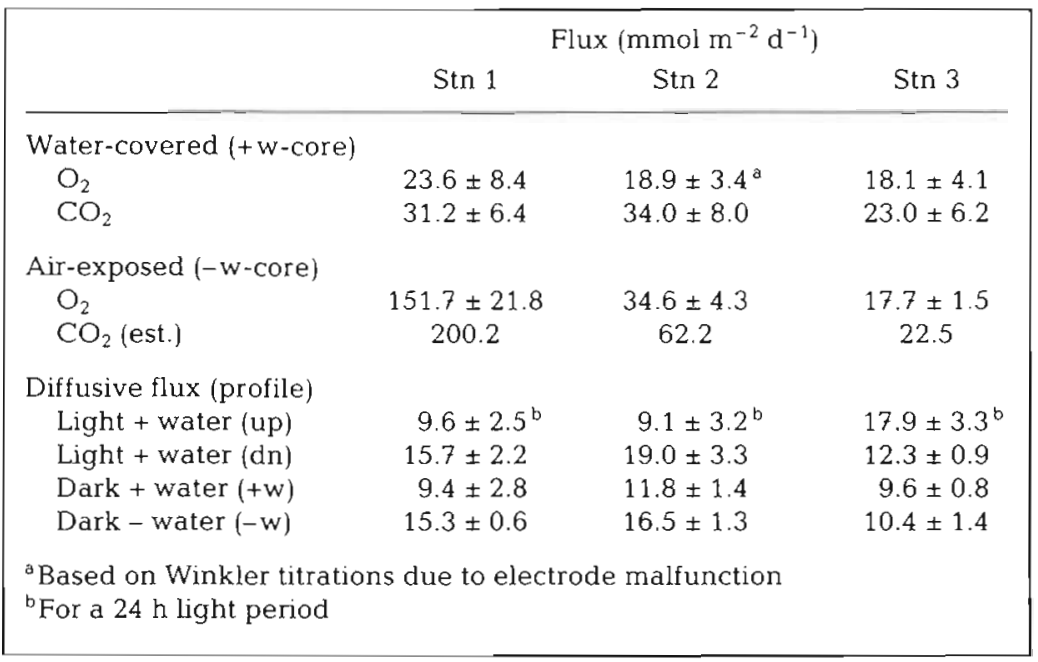




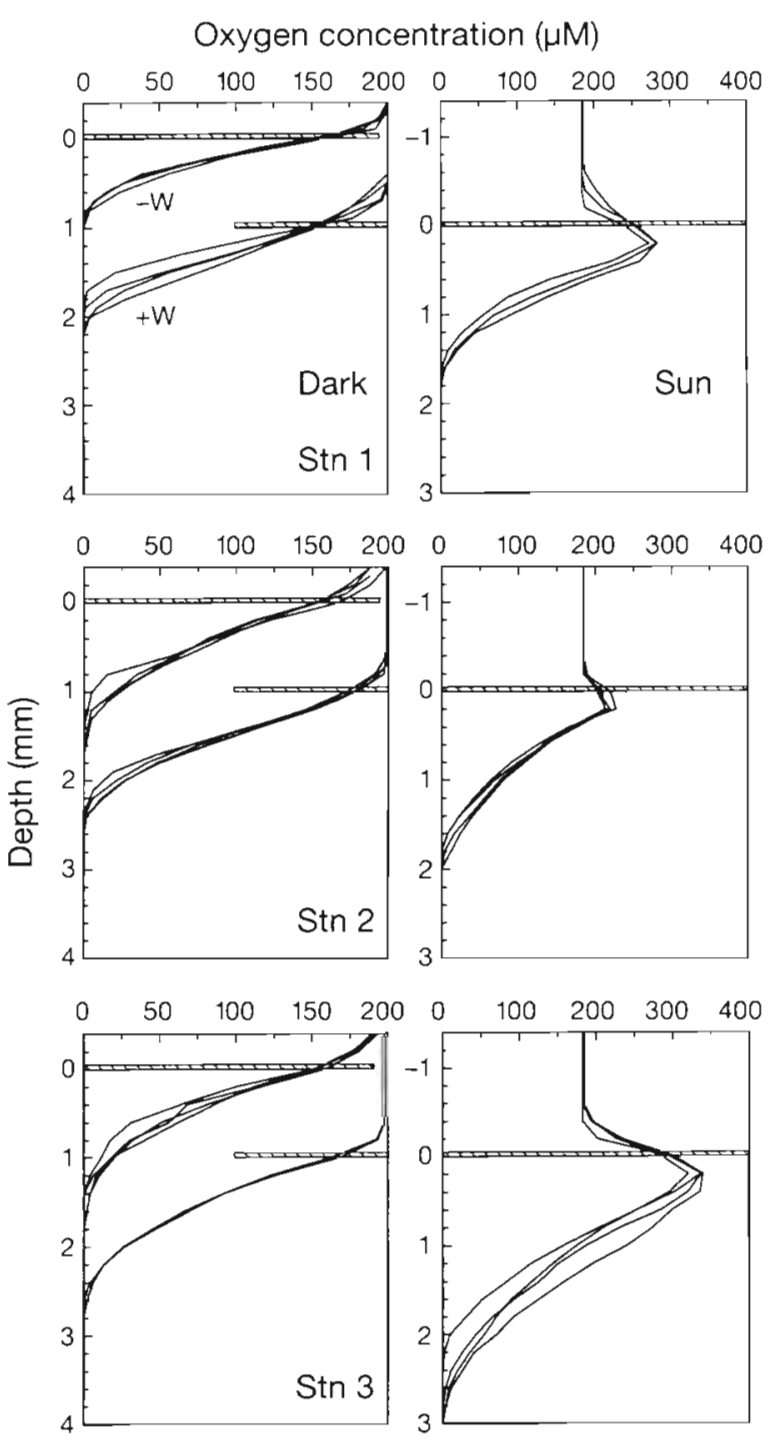

Fig. 2. Vertical profiles of oxygen in the surface sediment at Stns 1, 2 and 3. Profiles are shown for inundated $(+w)$ and airexposed $(-w)$ sediment in darkness (Dark) and inundated sediment exposed to sunlight (Sun). Horizontal bars indicate the sediment-water interface. In the 'Dark' panel the $-w$ and $+w$ profiles have been displaced $1 \mathrm{~mm}$ for simplicity (the $+w$ profile refers to the depth scale of the 'Sun' panel). Each profile contains 2 to 4 individual measurements

estimated daily $\mathrm{CO}_{2}$ release at Stns 1,2 and 3, respectively. Rates of sulfate reduction integrated over the depth interval examined for acetate uptake 10 to $11 \mathrm{~cm}$ ) only accounted for 35 to $55 \%$ of the 0 to $30 \mathrm{~cm}$ integrated rates.

\section{Acetate turnover}

Acetate concentrations varied markedly as a function of station, depth and pore water collection method
Table 2. Average diurnal $\mathrm{O}_{2}$ uptake and $\mathrm{CO}_{2}$ production (monthly average) by the sediment at the 3 stations, and time exposed to air per $24 \mathrm{~h}$

\begin{tabular}{|lccc|}
\hline & Stn 1 & Stn 2 & Stn 3 \\
\hline $\begin{array}{l}\mathrm{O}_{2} \text { uptake } \\
\left(\mathrm{mmol} \mathrm{m}^{-2} \mathrm{~d}^{-1}\right)\end{array}$ & 143.7 & 29.8 & 17.8 \\
$\begin{array}{l}\mathrm{CO}_{2} \text { production } \\
\left(\mathrm{mmol} \mathrm{m}^{-2} \mathrm{~d}^{-1}\right)\end{array}$ & 189.7 & 53.6 & 22.7 \\
$\begin{array}{l}\text { Air exposure } \\
\left(\mathrm{h} \mathrm{d}^{-1}\right)\end{array}$ & 22.5 & 16.7 & 14.4 \\
\hline
\end{tabular}

(Table 4, Fig. 4). Stn 3 had much lower concentrations than Stn 2. Concentrations generally increased with depth over the upper $11 \mathrm{~cm}$ at Stn 3 . In contrast, a subsurface maximum at $5 \mathrm{~cm}$ was observed for Stn 2 . Acetate was significantly $(\mathrm{p}<0.01)$ lower in pore water collected with sippers than in pore water collected by centrifugation at Stn 3; differences were less pronounced and not significant ( $p>0.1)$ at Stn 2 (Fig. 4).

Rates of acetate uptake were higher at $\operatorname{Stn} 2$ than at Stn 3 (Table 4). This was primarily due to differences in pore water acetate concentrations, since uptake rate constants and turnover times were 2- to 3-fold greater and faster, respectively, at Stn 3 than at Stn 2. As no pronounced trends in uptake rate constants were evident as a function of depth at either station, the patterns of uptake rate with depth were also determined by acetate concentrations (Fig. 4). Acetate uptake at Stn 3 was estimated using the sipper concentration only, as values from centrifuged pore water were considered erroneously high due to a processing artifact. Rates at Stn 2 were estimated using pore water concentrations obtained by both sippers and centrifugation. Integrated uptake rates were about 2.6 times the rates of $\mathrm{CO}_{2}$ emission and 5 to 6 times the 0 to $11 \mathrm{~cm}$ integrated sulfate reduction at both Stns 2 and 3 (Table 3).

Acetate accumulated as a linear function of time in sodium molybdate inhibited cores $(0$ to $3 \mathrm{~cm}$ depth interval) from Stn 3 (Fig. 5). No significant increase

Table 3. Depth-integrated sulfate reduction ( $\Sigma \mathrm{SRR}, \mathrm{mmo}$ ) $\left.\mathrm{m}^{-2} \mathrm{~d}^{-1}\right)$ in the intervals 0 to 30 and 0 to $11 \mathrm{~cm}$, and acetate uptake $\left(\sum \mathrm{AU}, \mathrm{mmol} \mathrm{m} \mathrm{m}^{-2} \mathrm{~d}^{-1}\right)$ in the 0 to $11 \mathrm{~cm}$ depth interval. Values in brackets are $\Sigma$ SRR and $\sum A U$ in \% of the estimated diurnal $\mathrm{CO}_{2}$ emissions

\begin{tabular}{|cccc|}
\hline & Stn 1 & Stn 2 & $\operatorname{Stn} 3$ \\
\hline$\sum \operatorname{SRR}(0$ to $30 \mathrm{~cm})$ & $10.0(11 \%)$ & $22.9(85 \%)$ & $10.4(92 \%)$ \\
$\sum \operatorname{SRR}(0$ to $11 \mathrm{~cm})$ & $3.5(4 \%)$ & $12.0(45 \%)$ & $5.9(52 \%)$ \\
$\sum$ AU (0 to $\left.11 \mathrm{~cm}\right)$ & - & $69.5(260 \%)$ & $29.1(256 \%)$ \\
\hline
\end{tabular}


Fig. 3. Vertical distribution of sulfate reduction rates (SRR) at the 3 stations. Values are presented as mean $( \pm \mathrm{SD}$ ) of 3 determinations

\section{$\operatorname{SRR}\left(\mathrm{nmol} \mathrm{cm}-3 \mathrm{~d}^{-1}\right)$}
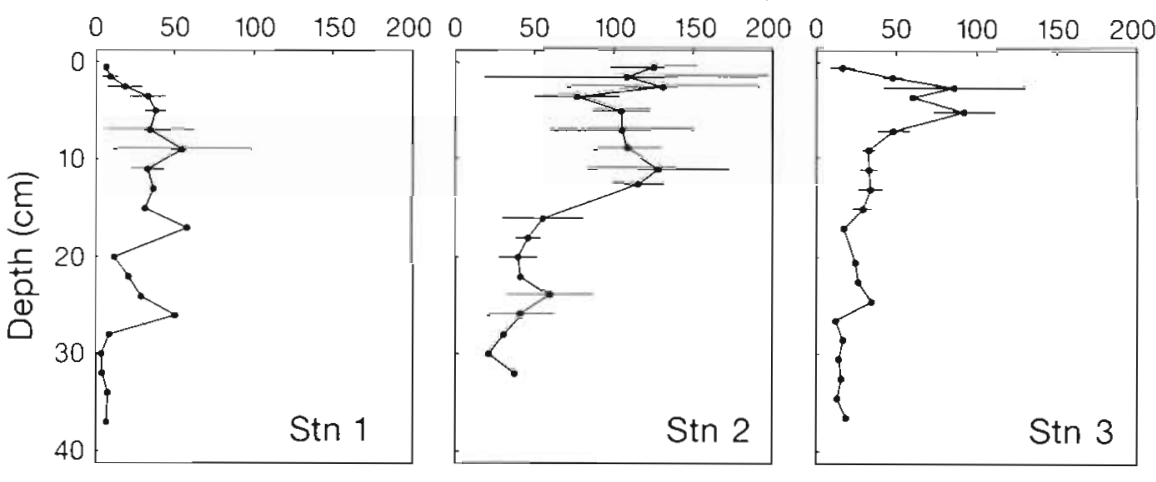

( $\mathrm{p}>0.1$ ) was observed for acetate concentrations in control cores. Rates of acetate accumulation in the presence of molybdate were approximately $17.7 \mathrm{nmol}$ $\mathrm{cm}^{-3} \mathrm{~d}^{-1}$, or about $50 \%$ of the rates estimated from the radioacetate uptake analysis for the same depth interval.

\section{DISCUSSION}

Rates of sediment $\mathrm{O}_{2}$ uptake and $\mathrm{CO}_{2}$ production varies considerably within and between intertidal zones in the Ao Nam Bor mangrove. Tidal influence was evident only in the high- and mid-intertidal zones (Stns 1 and 2) as 2 to 7 times higher $\mathrm{O}_{2}$ uptake in air-exposed $(-w)$ than water-covered $(+w)$ sediment (Table 1). A similar pattern has previously been

Table 4. Acetate pool sizes, uptake rate constants and uptake rates at Stns 2 and 3. Concentrations are means of triplicate sipper assays ( \pm SE); uptake rate constants are determined from means of quintuple time course assays for each depth interval $( \pm \mathrm{SE})$

\begin{tabular}{|c|c|c|c|c|}
\hline $\begin{array}{l}\text { Depth } \\
(\mathrm{cm})\end{array}$ & $\begin{array}{l}\text { Rate constants } \\
\qquad\left(\min ^{-1}\right)\end{array}$ & $\begin{array}{l}\text { Turnover time } \\
\text { (min) }\end{array}$ & $\begin{array}{c}\text { OAc pool size } \\
(\mu \mathrm{M})\end{array}$ & $\begin{array}{c}\text { Uptake rate } \\
\left(\mathrm{nmol} \mathrm{cm} \mathrm{cm}^{-3} \mathrm{~d}^{-1}\right)\end{array}$ \\
\hline \multicolumn{5}{|l|}{$\operatorname{Stn} 2$} \\
\hline 1 & $0.036(0.012)$ & 19.5 & $16.2(13.4)$ & 452 \\
\hline 3 & $0.016(0.006)$ & 43.0 & $20.5^{a}$ & 258 \\
\hline 5 & $0.046(0.013)$ & 15.0 & $31.3(20.0)$ & 1243 \\
\hline 7 & $0.049(0.008)$ & 14.3 & $16.4^{\mathrm{d}}$ & 757 \\
\hline 11 & $0.033(0.009)$ & 21.1 & $13.3^{\mathrm{d}}$ & 410 \\
\hline \multicolumn{5}{|l|}{$\operatorname{Stn} 3$} \\
\hline 1 & $0.097(0.016)$ & 7.1 & $0.5(0.3)$ & 33 \\
\hline 3 & $0.090(0.015)$ & 7.7 & $3.4(0.3)$ & 232 \\
\hline 5 & $0.079(0.008)$ & 8.8 & $3.4(0.7)$ & 199 \\
\hline 7 & $0.089(0.007)$ & 7.8 & $6.5(0.7)$ & 432 \\
\hline 11 & $0.086(0.005)$ & 8.1 & $5.4(0.4)$ & 348 \\
\hline
\end{tabular}

Acetate concentration $(\mu \mathrm{M})$

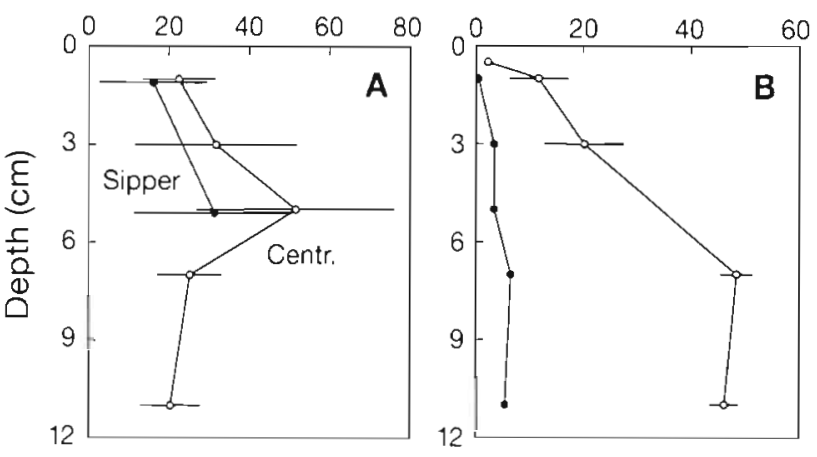

Fig. 4. Acetate concentrations at (A) Stn 2 and (B) Stn 3. sipper samples; $\circ$ : samples obtained by centrifugation. Error bars are $\pm \mathrm{SE}$, and are within the symbols for the sipper samples

reported from mangroves and salt marshes (Montague 1982, Dye 1983, Smith et al. 1983, Morris \& Whiting 1986, Brotas et al. 1990, Kristensen et al. 1992). Kristensen et al. (1992) ascribed the difference to an increased area of oxic-anoxic interfaces during air exposure. Drainage of water from sediment interstices (burrows and cracks) exposes sites to $\mathrm{O}_{2}$ which are otherwise anoxic. At the high-intertidal Stn 1 the high density of burrows make the sediment look like a 'Swiss cheese', whereas the other extreme, the low-intertidal Stn 3 , is wave exposed with a smooth or rippled sediment surface. However, 10 to $50 \%$ of the variation in core fluxes between air exposure and water cover at Stns 1 and 2 can be explained by changes in diffusive flux (Table 1). Diffusive flux of $\mathrm{O}_{2}$ is closely related to the boundary layer thickness (Jørgensen \& Des Marais 1990), which — in contrast to 


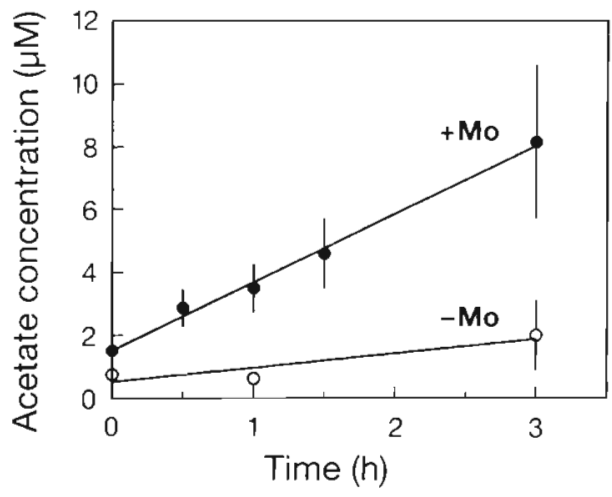

Fig. 5. Accumulation of acetate in intact subcores from Stn 3 incubated with $(\bullet)$ and without $(0)$ sodium molybdate. Error bars are $\pm \mathrm{SE}$

the $\mathrm{O}_{2}$ profiles shown in Fig. 2 - is thinner in airexposed than water-covered sediment. By relating measured and profile estimated rates of $\mathrm{O}_{2}$ uptake, the high-intertidal zone has a sediment-air contact zone 4 times larger than that of the low-intertidal zone, and 3 times larger than that of the mid-intertidal zone, which has a rough and irregular surface without crab burrows.

Detritus in mangrove sediments is usually of low quality for decomposers due to the high lignin and low nitrogen content (Benner \& Hodson 1985, Kristensen 1990, Lee et al. 1990) as shown here by the observed high C:N ratios (20 to 33 ) and $R p$ values ( 0.52 to 0.75 ) (Fig. 1). The poor detritus quality may explain the generally low fluxes of $\mathrm{O}_{2}$ and $\mathrm{CO}_{2}$ in water-covered mangrove sediments compared to other coastal environments (Colijn \& de Jonge 1984, King et al. 1985, Mackin \& Swider 1989, Kristensen 1993). The large difference in total metabolic activity between the highand mid-intertidal zones, which is inversely related to the bulk organic content of the sediments (Table 1 , Fig. 1A, B), cannot be explained by detritus quality alone, but is more likely a result of crab bioturbation (feeding and burrow construction). If the organic input (i.e. litter fall) is similar in these 2 zones, a 3 to 5 times stimulation of the decomposer community by crabs in the former zone (Stn 1) may evidently result in an overall lower organic content relative to the latter (Stn 2; Fig. 1). Other studies have also shown that activities of burrowing animals can stimulate benthic metabolism and cause a reduction of organic matter burial in marine sediments (Aller \& Yingst 1985, Kristensen 1988). The low fluxes at the low-intertidal Stn 3, however, correspond to the poor quality (high $\mathrm{C}: \mathrm{N}$ and $R p$ ) and small size of the detritus pool compared to the other stations. A significant fraction of benthic metabolism in this vegetation-free zone may, however, be supported by the decay of a dynamic pool of benthic microalgae as depicted by the relatively low $\mathrm{C}: \mathrm{N}$ ratio close to the sediment surface. The upward diffusive flux of $\mathrm{O}_{2}$, driven by benthic primary production, is on a daily basis (assuming a $12 \mathrm{~h}$ light period) equivalent to the downward diffusive flux and about half of the core flux in darkness. Studies from other tidal flat areas have reported that the benthic community is largely supported by benthic microalgal primary production (Colijn \& de Jonge 1984, Nowicki \& Nixon 1985, Kristensen 1993). The role of benthic microalgae is less pronounced in the vegetated mid-and high-intertidal zones based on both chlorophyll a content and the upward diffusive $\mathrm{O}_{2}$ flux ( 3 to $15 \%$ of diurnal uptake).

Sulfate reduction rates at Ao Nam Bor in January 1992 are comparable to those determined in the intertidal zone of a mangrove in Pakistan (Kristensen et al. 1992), but lower than those reported from most salt marshes (e.g. Skyring 1987) and tidal flats (e.g. Oenema 1990, M. H. Jensen unpubl.). The shape of the sulfate reduction profiles in Ao Nam Bor (Fig. 3) reflects the characteristics of each intertidal zone, e.g. vertical translocation of organic substrates due to subsurface root growth (Stn 2) or downward transport by crab bioturbation (Stn 1) and wave action (Stn 3). The low rates and irregular variations observed with depth at the high-intertidal Stn 1 are in accordance with the oxidized and heterogeneous sediment appearance. Most benthic respiration in this zone must be supported by electron acceptors other than $\mathrm{SO}_{4}{ }^{2-}$ (e.g. $\mathrm{O}_{2}$, $\mathrm{NO}_{3}{ }^{-}, \mathrm{Mn}^{4+}, \mathrm{Fe}^{3+}$ ), since sulfate reduction only could account for $11 \%$ of the total diurnal $\mathrm{CO}_{2}$ release (Table 3). Sulfate reduction usually supports more than $50 \%$ of the measured $\mathrm{CO}_{2}$ release in coastal sediments (Jørgensen 1983, Mackin \& Swider 1989). At the midintertidal Stn 2, live roots in the upper, active root zone (5 to $15 \mathrm{~cm}$ ) apparently supplied sulfate reducers with labile substrates. The lower rates below indicate substrate limitation in a zone where dead and lignified roots dominate. Live roots are known to excrete labile DOC (Stanley et al. 1987, Capehart \& Hackney 1989), whereas lignified vascular plant remains resist microbial decay (Crawford \& Crawford 1976, Benner et al. 1984, Lee et al. 1990). On the tidal flat (Stn 3), sulfate reduction exhibited a depth profile typical for coastal marine sediments where organic matter is supplied from above (Berner 1980, Jørgensen 1983). Peak rates within the upper $5 \mathrm{~cm}$ were followed by a rapid and exponential decrease to very low levels at $30 \mathrm{~cm}$ (in the coral sand). In the latter 2 intertidal zones (Stns 2 and 3), sulfate reduction was the most important respiration process, supporting around $90 \%$ of the total diurnal $\mathrm{CO}_{2}$ release (Table 3), indicating that $\mathrm{O}_{2}$ and $\mathrm{NO}_{3}^{-}$respiration, for example, was negligible.

Acetate is the most important carbon source for sulfate reducers in these sediments and its production 
rate via fermentation may control anaerobic respiration. The measured acetate uptake rates, however, exceed the rates of both total $\mathrm{CO}_{2}$ production and sulfate reduction expressed in acetate equivalents (Table 3). A similar discrepancy was noted by Christensen \& Blackburn (1982) which they attributed to overestimates of the biologically available acetate pool. This conclusion has been supported by others (e.g. Parkes et al. 1984, Michelson et al. 1989), although Shaw \& McIntosh (1990) suggested that artifacts in sample processing could lead to erroneously high pool sizes. However, both acetate pool sizes and uptake rates in the mid- and low-intertidal zones compare well with ranges reported by others for nearshore marine sediments (Ansbæk \& Blackburn 1980, Sansone \& Martens 1981, Balba \& Nedwell 1982, Christensen \& Blackburn 1982, Michelson et al. 1989 , Shaw \& McIntosh 1990, King 1991).

Problems with 'biologically unavailable, but chemically measured' acetate pools should be minimal in this study, since acetate concentrations were assayed using an enzymatic method that presumably detects only those pools available to bacteria. The pool sizes might still have been overestimated though. Results from the molybdate inhibition incubation provide some, though not conclusive support, for concentration artifacts in the sipper samples (Fig. 5). The rate of acetate accumulation is 2 -fold lower than the rate of oxidation calculated from uptake rate constants and sipper-based pool sizes for a similar depth interval (Table 4). If the slope of acetate accumulation in the molybdate-treated samples is unaffected by the use of centrifugation to collect pore water, then the molybdate-based estimate of acetate metabolism could more closely approximate the true rate. In fact, the difference between the molybdate-based and radiotracer/sipper-based rates is consistent with the discrepancy between the latter and the sulfate reduction rates, suggesting that the rates based on molybdate inhibition are more accurate. Although a more critical evaluation of the various methods for estimating rates and collecting pore water is required, molybdate inhibition perhaps offers the least problematic approach, subject to constraints discussed by Michelson et al. (1989). Previous estimates of acetate uptake based on radiotracer analysis have often exceeded rates predicted from parallel analysis of sulfate reduction (Christensen \& Blackburn 1982, Shaw et al. 1984), while acetate uptake rates derived from molybdate inhibition have been consistent with sulfate reduction (Sørensen et al. 1981, Christensen 1984).

The results from both benthic 'whole-core' fluxes and sulfate reduction in the present study indicate that benthic metabolism in the Ao Nam Bor mangrove was low in 1992 compared with results obtained by Kris-
Table 5. Comparison of sediment $\mathrm{O}_{2}$ uptake, $\mathrm{CO}_{2}$ production and sulfate reduction $\left(0\right.$ to $10 \mathrm{~cm}$, all in $\mathrm{mmol} \mathrm{m} \mathrm{m}^{-2} \mathrm{~d}^{-1}$ ) measured at 3 stations in the Ao Nam Bor mangrove forest in 1990 (Kristensen et al. 1991) and 1992 (this study). R(90/92): ratio between results obtained in 1990 and 1992

\begin{tabular}{|lccc|}
\hline Stn & 1990 & 1992 & $\mathrm{R}(90 / 92)$ \\
\hline $\mathrm{O}_{2}$ uptake & & & \\
1 & 61 & 24 & 2.5 \\
2 & 45 & 19 & 2.4 \\
3 & 50 & 18 & 2.8 \\
$\mathrm{CO}_{2}$ production & & & \\
1 & 86 & 31 & 2.8 \\
2 & 70 & 34 & 2.9 \\
3 & 77 & 23 & 3.3 \\
Sulfate reduction & & & \\
1 & 28 & 4 & 7.0 \\
2 & 50 & 12 & 4.2 \\
3 & 43 & 6 & 7.3 \\
\hline
\end{tabular}

tensen et al. (1991) at the same site in January 1990. Their flux rates were 2 to 3 times higher and sulfate reduction rates 4 to 7 times higher than in the present study (Table 5). The relative differences in rates between the zones, however, were similar in both years. The causes for this discrepancy are not quite clear. A similar large interannual variability of benthic metabolism and sulfate reduction in a Spartina marsh has been ascribed to changes in primary production and thus the lability of sediment detritus (Hines et al. 1989). Mangrove swamps are generally characterized as environments of great temporal and spatial variations in biological activity due to variability in parameters such as monsoonal rains, tidal inundation and human impact (e.g. Chansang et al. 1982, Alongi 1989). The presently observed year-to-year variation in benthic metabolism may be caused by changes in the input of leaf detritus, as the January litter fall has decreased gradually from $2.7 \mathrm{~g}$ dry wt $\mathrm{m}^{-2} \mathrm{~d}^{-1}$ in 1985 to $1.4 \mathrm{~g}$ dry wt $\mathrm{m}^{-2} \mathrm{~d}^{-1}$ in 1992 (L. H. Kofoed pers. comm.). Furthermore, the monsoon periods preceding the 1992 study may have caused a deposition of low reactive detritus in the Ao Nam Bor mangrove system, which has previously been dregded from deep layers in the seabed by nearby offshore tin mining plants (Chansang et al. 1982, Hylleberg \& Nateewathana 1984). However, in order to fully elucidate the causes for the observed discrepancy between the 2 years, further work on factors controlling the interannual variability of sediment metabolism in mangroves is needed.

Acknowledgements. We are grateful to the staff of PMBC for providing facilities and invaluable assistance during this study. We thank $\mathrm{H}$. Brandt for technical assistance. This work was supported by grant no. 91-0542/60 from the Carlsberg Foundation. 


\section{LITERATURE CITED}

Aller, R. C., Yingst, J. Y (1985). Effects of the marine depositfeeders Heteromastus filiformis, Macoma balthica and Tellina texana on averaged sedimentary solute transport, reaction rates and microbial distribution. J. mar. Res. 43 : $615-645$

Alongi, D. M. (1989). The role of soft-bottom benthic communities in tropical mangrove and coral reef ecosystems. Rev. aquat. Sci. 1: 243-280

Ansbæk, J., Blackburn, T. H. (1980). A method for the analysis of acetate turnover in a coastal marine sediment. Microb. Ecol. 5: 253-264

Balba, M. T., Nedwell, D. B. (1982). Microbial metabolism of acetate, propionate and butyrate in anoxic sediment from the Colne Point saltmarsh, Essex, U.K. J. gen. Microbiol. 128: 1415-1422

Benner, R., Hodson, R. E. (1985). Microbial degradation of the leachable and lignocellulosic components of leaves and wood from Rhizophora mangle in a tropical mangrove swamp. Mar. Ecol. Prog. Ser. 23: 221-230

Benner, R., Maccubbin, A. E., Hodson, R. E. (1984). Preparation, characterization and microbial degradation of specifically radiolabeled $\left[{ }^{14} \mathrm{C}\right.$ lignocelluloses from marine and freshwater macrophytes. Appl, environ. Microbiol. 47 : 381-389

Berner, R. A. (1980). Early diagenesis. Princeton University Press, Princeton, NJ

Broecker, W. S., Peng, T.-H. (1974). Gas exchange rates between air and sea. Tellus 26: 21-35

Brotas, V., Amorim-Ferreira, A., Vale, C., Catarino, F. (1990). Oxygen profiles in intertidal sediments of Ria Formosa (S. Portugal). Hydrobiologia 207: 123-129

Capehart, A. A., Hackney, C. T (1989). The potential role of roots and rhizomes in structuring salt-marsh benthic communities. Estuaries 12: 119-122

Chansang, H., Poovachiranon, S., Wungboonkong, C. (1982). Human impact on a mangrove forest on Phuket Island, Thailand. Biotrop. Spec. Publ. 17: 45-54

Christensen, D. (1984). Determination of substrates oxidized by sulfate reduction in intact cores of marine sediments. Limnol. Oceanogr. 29: 189-192

Christensen, D., Blackburn, T. H. (1982). Turnover of ${ }^{14} \mathrm{C}$ labelled acetate in marine sediments. Mar. Biol. 71: $113-119$

Colijn, F., de Jonge, V. N. (1984). Primary production of microphytobenthos in the Ems-Dollard estuary. Mar. Ecol. Prog. Ser. 14: 185-196

Crawford, D. L., Crawford, R. L. (1976). Microbial degradation of lignocellulose: the lignin component. Appl. environ. Microbiol. 31: 714-717

Dye, A. H. (1983). Oxygen consumption by sediments in a Southern African mangrove swamp. Estuar. coast. Shelf Sci. 17: 473-478

Enriquez, S., Duarte, C. M., Sand-Jensen, K. (1993). Patterns in decomposition rates among photosynthetic organisms: the importance of detritus C:N:P content. Oecologia 94: $457-471$

Flores-Verdugo, F. J., Day, J. W., Briseno-Duenas, R. (1987), Structure, litter fall, decomposition, and detritus dynamics of mangroves in a Mexican coastal lagoon with an ephemeral inlet. Mar. Ecol. Prog. Ser. 35: 83-90

Fossing, H., Jørgensen, B. B. (1989). Measurement of bacterial sulfate-reduction in sediments: evaluation of a single-step chromium reduction method. Biogeochemistry 8: 205-222

Frith, D. W. Tantanasiriwong, R., Bhatia, O. (1976). Zona- tion and abundance of macrofauna on a mangrove shore, Phuket Island. Res. Bull. Phuket mar. Biol. Cent. 6: $1-37$

Gonzalez-Farias, F., Mee, L. D. (1988). Effect of mangrove humic-like substances on biodegradation rate of detritus. J. exp. mar. Biol. Ecol. 119: 1-13

Helder, W. Bakker, J. F. (1985). Shipboard comparison of micro- and minielectrodes for measuring oxygen distribution in marine sediments. Limnol. Oceanogr. 30: 1106-1109

Hines, M. E., Knollmeyer, S. L., Tugel, J. B. (1989). Sulfate reduction and other sedimentary biogeochemistry in a northern New England salt marsh. Limnol. Oceanogr. 34: $578-590$

Howes, B. L., Dacey, J. W. H., Wakeham, S. G. (1985). Effects of sampling technique on measurements of pore water constituents in salt marsh sediments. Limnol. Oceanogr. 30: $221-227$

Hylleberg, J., Nateewathana, A. (1984). Response of polychaete families to monsoon and offshore mining - associated sediment disturbance. In: Hutchings, P. A. (ed.) Proc. 1st int. Polychaete Conf. The Linnean Soc., Sydney. p. $279-291$

Jørgensen, B. B. (1978). A comparison of methods for the quantification of bacterial sulfate reduction in coastal marine sediments. Geomicrobiol. J. 1: 11-27

Jørgensen, B. B. (1983). Processes at the sediment-water interface. In: Bolin, B., Cook, R. B. (eds.) The major biogeochemical cycles and their interactions. John Wiley, Chichester, p. 477-509

Jørgensen, B. B., Des Marais, D. J. (1990). The diffusive boundary layer of sediments: oxygen microgradients over a microbial mat. Limnol. Oceanogr. 35: 1343-1355

King, G. M. (1988). Patterns of sulfate reduction and the sulfur cycle in a South Carolina salt marsh. Limnol. Oceanogr. 33: $376-390$

King, G. M. (1991). Measurement of acetate concentrations in marine pore waters by using an enzymatic approach. Appl. environ. Microbiol. 57: 3476-3481

King, G. M., Howes, B. L., Dacey, J. W. H. (1985). Short-term endproducts of sulfate reduction in a salt marsh: formation of acid volatile sulfides, elemental sulfur, and pyrite. Geochim. Cosmochim. Acta 49: 1561-1566

Komiyama, A., Ogino, K., Aksornkoae, S., Sabhasri, S. (1987). Root biomass of a mangrove forest in southern Thailand. 1. Estimation by the trench method and the zonal structure of root biomass. J. Trop. Ecol. 3: 97-108

Kristensen, E. (1988). Benthic fauna and biogeochemical processes in marine sediments: microbial activities and fluxes. In: Blackburn, T. H., Sørensen, J. (eds.) Nitrogen cycling in coastal marine environments. John Wiley, Chichester, p. 275-299

Kristensen, E. (1990). Characterization of biogenic organic matter by stepwise thermogravimetry (STG). Biogeochemistry 9: 135-159

Kristensen, E. (1993). Seasonal variation in benthic community metabolism and nitrogen dynamics in a shallow organic-poor Danish lagoon. Estuar. coast. Shelf Sci. 37; 565-586

Kristensen, E., Devol, A. H., Ahmed, S. I., Saleem, M. (1992). Preliminary study of benthic metabolism and sulfate reduction in a mangrove swamp of the Indus Delta, Pakistan. Mar. Ecol. Prog. Ser. 90: 287-297

Kristensen, E., Holmer, M., Bussarawit, N. (1991). Benthic metabolism and sulfate reduction in a southeast Asian mangrove swamp. Mar. Ecol. Prog. Ser. 73: 93-103

Lee, K.-H., Moran, M. A., Benner, R., Hodson, R. E. (1990). Influence of soluble components of red mangrove (Rhizo- 
phora mangle) leaves on microbial decomposition of structural (lignocellulosic) leaf components in seawater. Bull. mar. Sci. 46: 374-386

Lugo, A. E., Snedaker, S. C. (1974). The ecology of mangroves. A. Rev. Ecol. Syst. 5: 39-64

Mackin, J. E., Swider, K. T. (1989). Organic matter decomposition pathways and oxygen consumption in coastal marine sediments. J. mar. Res. 47:681-716

Michelson, A. R., Jacobsen, M. E., Scranton, M. I., Mackin, J. E. (1989). Modeling the distribution of acetate in anoxic estuarine sediments. Limnol. Oceanogr. 34: 747-757

Montague, C. L. (1982). The influence of fiddler crab burrows and burrowing on metabolic processes in salt marsh sediments. In: Kennedy, V. S. (ed.) Estuarine comparisons. Academic Press, New York, p. 283-301

Morris, J. T., Whiting, G. J. (1986). Emission of gaseous carbon dioxide from salt-marsh sediments and its relation to other carbon losses. Estuaries 9: 9-19

Nedwell, D. B., Abram, J. W. (1978). Bacterial sulphate reduction in relation to sulphur geochemistry in two contrasting areas of saltmarsh sediment. Estuar. coast. Shelf Sci. 6: $341-351$

Nowicki, B. L., Nixon, S. W. (1985). Benthic community metabolism in a coastal lagoon ecosystem. Mar. Ecol. Prog. Ser. 22: 21-30

Oenema, O. (1990). Sulfate reduction in fine-grained sediments in the Eastern Scheldt, southwest Netherlands. Biogeochemistry 9: $53-74$

Parkes, R. J., Taylor, J., Jorck-Ramberg, D. (1984). Demonstration, using Desulfobacter spp., of two pools of acetate with different biological availabilities in marine pore water. Mar. Biol. 83: 271-276

Parsons, T. R., Maita, Y., Lalli, C. M. (1984). A manual of chemical and biological methods for seawater analysis. Pergamon, Oxford

This article was submitted to the editor
Robertson, A. I, Daniel, P. A. (1989). The influence of crabs on litter processing in high intertidal mangrove forests in tropical Australia. Oecologia 78: 191-198

Sansone, F. J., Martens, C. S. (1981). Determination of volatile fatty acid turnover rates in organic-rich marine sediments. Mar. Chem. 10: 233-247

Sawyer, T. E., King, G. M. (1993). Glucose uptake and end product formation in an intertidal marine sediment. Appl. environ. Microbiol. 59: 120-128

Shaw, D. G., Alperin, M. J., Reeburgh, W. S., McIntosh, D. J. (1984). Biogeochemistry of acetate in anoxic sediments of Skan Bay, Alaska. Geochim. Cosmochim. Acta 48: $1819-1825$

Shaw, D. G., Mclntosh, D. J. (1990). Acetate in recent anoxic sediments: direct and indirect measurements of concentration and turnover rates. Estuar. coast. Shelf Sci. 31: $775-788$

Skyring, G. W. (1987). Sulfate reduction in coastal ecosystems. Geomicrobiol. J. 5: 295-373

Smith, C. J., DeLaune, R. D., Patrick, W. H. (1983). Carbon dioxide emission and carbon accumulation in coastal wetlands. Estuar. coast. Shelf Sci. 17: 21-29

Sørensen, J., Christensen, D., Jørgensen, B. B. (1981). Volatile fatty acids and hydrogen substrates for sulfate-reducing bacteria in anaerobic marine sediment. Appl. environ. Microbiol. 42: 5-11

Stanley, S. O., Boto, K. G., Alongi, D. M., Gillan, F. T. (1987). Composition and bacterial utilization of free amino acids in tropical mangrove sediments. Mar. Chem. 22: 13-30

Talling, F. (1973). The application of some electrochemical methods to the measurement of photosynthesis and respiration in fresh water. Freshwat. Biol. 3: $335-362$

Wattayakorn, G., Wolanski, E., Kjerfve, B. (1990). Mixing, trapping and outwelling in the Klong Ngao mangrove swamp, Thailand. Estuar. coast. Shelf Sci. 31: 667-688

Manuscript first received: September 3, 1993

Revised version accepted: March 30, 1994 